\title{
Knowledge Management Practices and Organizational Learning Have Positive Impacts on Organizational Performance of State-Owned Enterprises in Indonesia
}

\author{
Ade Irma Susanty, Ph.D1 \\ Madihah Salwa, S.M.B., M.M² \\ ${ }^{1}$ Business Administration Program, School of Communication and Business, Telkom University, Indonesia \\ ${ }^{2}$ Magister Management Program, School of Economic and Business, Telkom University, Indonesia
}

\author{
Doi:10.5901/mjss.2017.v8n3p281
}

\section{Abstract}

The performance of state-owned enterprises (SOEs) is rated as an important component of the economic development in Indonesia. Indonesian government has set strategic steps to fix the financial value of the SOEs. Knowledge management is one of strategic implementation of SOEs. The result of the researcher's analysis reveals that the implementation of the knowledge management does not always give a positive contribution to the performance of the SOEs. Accordingly, it is important to conduct a research related to the efforts taken in implementing knowledge management and its impacts on organizational performance of the SOEs. The main objective of this study is to figure out the relationship between knowledge management and organizational performance by involving organizational learning as the intervening variable. This study involves six state-owned enterprises in Indonesia. The total number of respondents successfully examined were 189 employees of the six state-owned enterprises. The data was processed by SEM technique using AMOS 22 Software and the result shows that knowledge management has a significant impact by $45 \%$ toward organizational performance, and organizational learning influences significantly by $44 \%$ on organizational performance.

Keywords: Knowledge Management Practices, Organizational Learning, Organizational Performance, Human Resources, State Owned Enterprise

\section{Introduction}

In one study, Gavrea et al. (2011) stated that an organization has an important role in the progress of a country. The economy of a nation is determined by the movement and development of the organizations, especially in the fields of business. One of the principal concerns of an organization or business is its performance. The performance of a company is generally measured through its revenues. However, other factors apart from the income can also be used as a benchmark to assess a company's performance. Carton et al. (2006) reported that within the scope of business, performance is a measurement determined by the management based on the results achieved by the organization in a certain period of time. Bagorogoza et al. (2013) mentioned that the performance of the organization is an achievement both in terms of financial and non-financial sides that has been achieved within the period of five to ten years. According to Carton et al. (2006), the concept of organizational performance assessment is formed based on the combined analysis results from the assets ie human assets, physical assets, and capital assets, to achieve certain purposes, thus the determination of an organizational performance value is not only emphasized on the financial assets only.

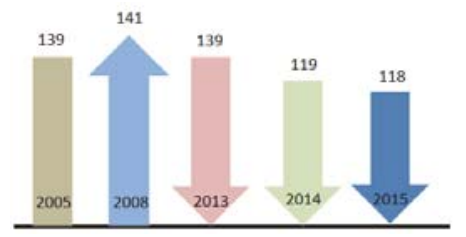

Figure 1. The development numbers of SOEs in Indoensia 2005 - 2015

Source: compliled by the writers (2016)

Associated with business organizations, the largest ones managed by the country are the State-Owned Enterprises (SOEs). Referring to the description of the Law of the Republic of Indonesia Number 19 of 2003, a SOE is a business 
entity of all or most of its capital owned by the country through direct investments taken from the wealth that has been allocated. The number of SOEs has progressed from year to year, as shown in Figure 1. The latest number in 2015 was 118 companies. The number is inversely proportional to the number of recorded human resources as the employees of SOEs. Related to the performance of the SOEs, in early 2016, several printed and online media in Indonesia proclaimed the business perfomance evaluation results of several companies throughout 2015 which showed the decreasing trends compared to the previous years. Additionally in 2015 the number of state-owned companies in unhealthy category was still considered high. The decline of the SOE performances at that time was due to various factors.

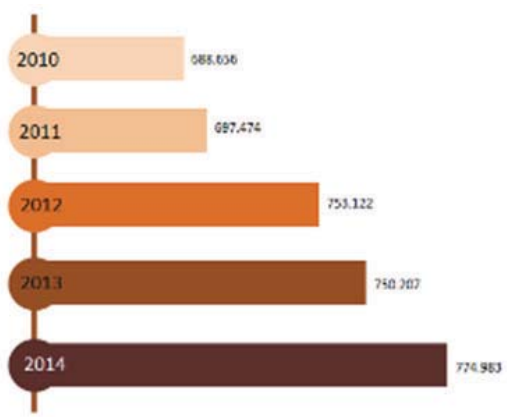

Figure 2. The Increasing Number of Employees in SOEs 2010 - 2014

Source: compliled by the writers (2016)

In an online media created by Fajriah (2015) the SOE Minister Rini Soemarno said the cause of the decline in the performance of SOEs is a result of the economic turmoil of the world which was unstable, such as the devaluation of the yuan, the low purchasing power of the society, and an increase in interest rates of The Fed. Considering that the stateowned enterprises play an important role as the agent of development, therefore the good and bad conditions of the SOEs have a large impact on the stability of Indonesian economy. Consequently, it is a must to continually take efforts in making the performances of the SOEs recover and grow. Based on the press release of the SOEs performance (2016), Minister Rini targeted the net profits of SOEs in 2016 should have risen from $12.20 \%$ to $14.67 \%$.

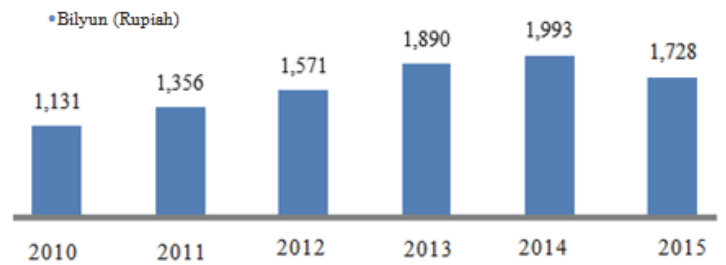

Figure 3. The condition of SOEs Revenue $2010-2015$

Source: compliled by the writers (2016)

In order to restore the health condition of the SOEs and achieve the targets, some of the strategies were promoted by the ministry of state enterprises, among which were the strategic projects in 2016: the development of infrastructure, defense, maritime, energy and food; SOE synergy; privatization of state enterprises; bureaucratic reform through knowledge management; and the most frequently echoed strategies were restructuring and the plan of holding some SOEs. One of the government's efforts to improve the conditions of the SOE performance was by implementing knowledge management. Related to the above mentioned, an article in the Harvard Business Review by Spreitzer (2012) stated that the company's progress derives from knowledge and skills.

The implementation of knowledge management has been introduced since 2002. The results of the annual evaluation reports of the state-owned enterprises from 2005 to 2014 revealed that at least 54 companies or equivalent with $46 \%$ of SOEs were recorded to have implemented knowledge management. Nevertheless, the authors exploration results related to the implementation of knowledge management in SOEs noted that not all the institutions which have implemented knowledge management provided good impact on improving the health of the companies, whereas the health category is one of the primary gauges of performance appraisal in the SOEs. Based on the results of the authors' 
exploration on management data in the state-owned enterprises from a total of 19 SOEs which are the representatives of each sector in Indonesia, 10 of them were mentioned to have stable values of performance after implementing knowledge management, six state-owned companies experienced the increase in the performance value after implementing knowledge management, and 3 other companies experienced the decrease in the criteria of healthy company after implementing knowledge management. The results of the research conducted by Hsu (2011) showed that the implementation of knowledge management has a major contribution to the performance of the company. Reinforced by the results of research that has been done by Andreeva (2012) which stated that knowledge management carried out through the management of human resources and technological assistance have a significant effect on the economy as well as the performance of the company. Rasula (2012) also noted that the good implementation of knowledge management will take the organization to achieve better organizational values.

In the implementation of knowledge management aimed at building a better performance of the organization, there are many other processes involved, one of which is organizational learning. Rehman, et al (2015) stated that organizational learning is a very important mediator between knowledge management and organizational performance. In relation to achieving organizational performance value of SOEs in order to achieve the set targets, the involvement of the activities of knowledge management and organizational learning process become important to know, that's why the researchers did the research.

\section{The Aim of Research}

This study was inspired by the data showing a decline in the performance of SOEs in 2015. The implementation strategy of knowledge management gives different impacts on the performance of the companies implementing knowledge management. Thus, in general, this study is carried out to determine the effects of implementing knowledge management and organizational learning on organizational performance. There are three research questions that must be answered: (1) Does the implementation of knowledge management affect organizational performance?; (2) Does the implementation of knowledge management affect organizational learning? ; and (3) Does the organizational learning affect organizational performance?.

\section{Overview of Knowledge Management, Organizational Learning, and Organizational Performance Theories}

According to Moeljono (2004) with reference to the master plan of SOEs from 2002 to 2006 related to the creation of value for financial and operational performance through corporate culture, such as the creation of knowledge management values, within that period of time knowledge management was introduced to SOEs. The implementation of knowledge management in SOEs is set up in the guidelines on how to implement it by regulation of the Minister for utilization of state apparatus and Bureaucratic Reform No. 14 in 2011. In the law, it is explained that knowledge management is an attempt to improve the organization's ability to manage its intellectual assets such as knowledge and experience. The purpose of establishing the implementation of knowledge management in SOEs environment is to utilize the company's assets to achieve a better organizational performance. In the regulation of bureaucratic reform No. 14 of 2011, it is stated that the implementation of knowledge management in SOEs uses the help of information technologybased system to manage the knowledge at every stage, either in the acquisition, storage, retrieval, use or improvement.

Grant in Chien (2012) stated that the resource of knowledge is the source of major strategy for an organization to compete. Having the ability to compete will help a company achieve a better organizational performance value easily. In this case, knowledge management plays a major role to create a lot of new knowledge from the employees. As described by Seidman (2014) that a basic factor of a company's success is the knowledge of the people in it. The effort to use and make the most of the tacit and explicit knowledge is by implementing knowledge management. The effort is considered as a strategy to create an execellent value of the organization. The results of research conducted by Darroch (2005) illustrated that there is a significant influence between the implementation of knowledge management and organizational performance even within a very small influence value. Quintane (2011) considered that the utilization and implementation of knowledge management are an effort to create innovations. Rasula (2012) explained the meaning of knowledge management as a process consisting of the creation, accumulation, organization, and use of knowledge to achieve certain goals and improve organizational performance. In the implementation of knowledge management there are strategies, cultural values, and the working style of an organization.

Griffith in Chien (2012) stated that the utilization of knowledge resources to achieve the development capability of the company must be accompanied by organizational learning activities. As argued by Spreitzer (2012) that two main components for a company to grow and develop are vitality and learning. 
Andone (2009) highlighted that the utilization of knowledge management can become a force in improving the performance of the company, its implementation must be tailored to the company's performance appraisal system. It means that knowledge management is involved as one of the indicators of organizational performance. In this case, the SOEs have not fully made the implementation of knowledge management as an organizational performance assessment indicator. While its implementation is still in the policies of each company and of course it is adapted to the corporate culture.

In this study, the researchers will test a model that had been developed and refers to the model that has been collated by leh Rehman, et al. (2015). The existing variables in this study are knowledge management practices, organizational learning, and organizational performance.

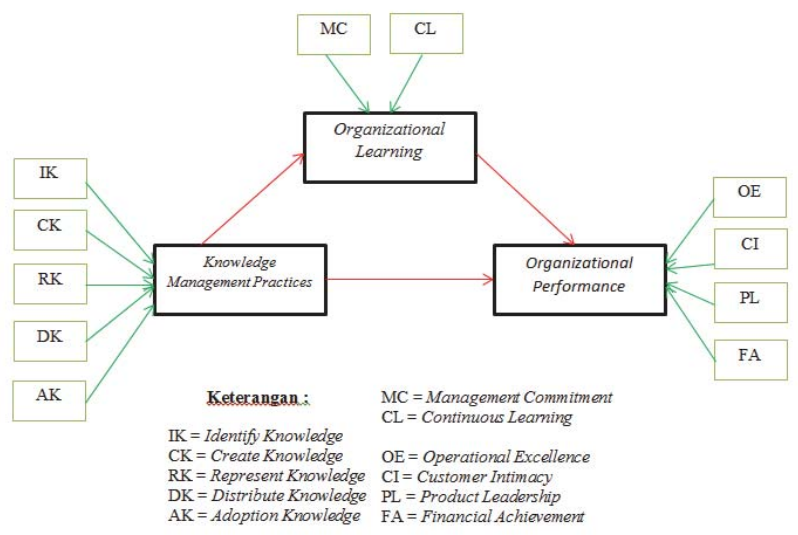

Figure 4. Research Model

Source: adopted from the research of Rehman, et al. (2015) \& Wu (2014)

\section{Knowledge Management}

The implementation of knowledge management in SOEs is set using the principle of three basic processes: (1) acquisition of knowledge; (2) sharing of knowledge; (3) utilization of knowledge. In this case the acquisition of knowledge is a process of acquisition or development of intellectual assets, including personal understanding, personal experience, personal skills, and relationships among the data. To facilitate this process, the government encourages state-owned enterprises to create an organizational knowledge database or commonly referred to as knowledge repository. The process of sharing knowledge is outlined in Bureaucratic reform No. 14 of 2011 stating that it is a process for distributing and making knowledge available to a wide range of people in need within the organization. This process is recommended by the government to be formed through a social process in accordance with the existing organizational culture. This process is also recommended to take place either traditionally through discussions and colloquia or through modern technology-based medium. In the last process regulated by the government saying that the utilization of knowledge is considered as the most important process to be be done by the SOEs. In this process, the activities to further develop and complement the gained knowledge also occur.

Mills (2011) explained that the meaning of knowledge management is a facility provided by the organization to facilitate the distribution of knowledge. The main objective of the implementation of knowledge management is to ensure that the individual's knowledge can be owned by the organization, so it will not be a big problem if someone who has valuable knowledge is no longer in the organization. Rasula (2012) stated that the successful implementation of knowledge management is when the employee's knowledge can become the organization's knowledge

The successful implementation of knowledge management can be achieved through four processes: (1) accumulation; (2) Utilization; (3) Sharing; (4) Ownership. Accumulation is the process of finding and collecting good knowledge either coming from inside the organization or outside the organization. Utilization is the process in which the knowledge needed by an organization has been already available and used by people in the organization. Sharing process is an attempt to distribute the knowledge more comprehensively. Ownership is the identification of the experts within the organization. Salwa and Susanty (2016) stated that knowledge management can be measured using SECI 
process that was firstly introduced by Nonaka and Takeuchi in 1995. The process comprises: (1) socialization; (2) externalization; (3) combination; and (4) Internalization. Socialization is the distribution process from tacit knowledge to tacit knowledge. Externalization is the distribution process from tacit knowledge into explicit knowledge. Combination is the distribution process from explicit knowledge into explicit knowledge. Internalization is the distribution process from explicit knowledge into tacit knowledge. Wu (2014) mentioned four processes that support successful implementation of knowledge management, namely: (1) creation process; (2) transfer process; (3) integration process; (4) application process. Rehman, et al. (2015) mentioned five main processes for identifying the knowledge management practices, namely: (1) identify knowledge; (2) create knowledge; (3) represent knowledge

\section{Organizational Learning}

Yeo (2003) explained that the concept of organizational learning has been introduced since 1995. The concept was introduced for people in the organization to be able to contribute positively to the management. The positive contribution can be explained through organizational learning. Organizational learning is a natural process that occurs in the development of an individual knowledge value to improve the adaptability of an organization in the business competition (Molina, 2009). Organizational learning is a learning process carried out by individuals in an organization, based on what has been a provision in it (Rehman, et al., 2015). Figurska (2016) explained the meaning of learning as follows:

learning is an activity accompanying a human being since the dawn of history, and ever since philosophers, psychologists and educators have tried to explore its essence by presenting the result of their research and reflections in the form of learning theories'.

The meaning of organizational learning has grown very widely, among the definitions that have been described by the previous researchers, the writers can interpret it as an organizational effort to establish its employees or members of their organization to be human learners. In the activities, it is frequently associated with learning organization. Eventhough it may seem the same at first glance, organizational learning and learning organizational is different. Bordum (2001) mentioned the difference between organizational learning and learning organization as follows:

Table 1. The Differences Between Learning Organization and Organizational Learning

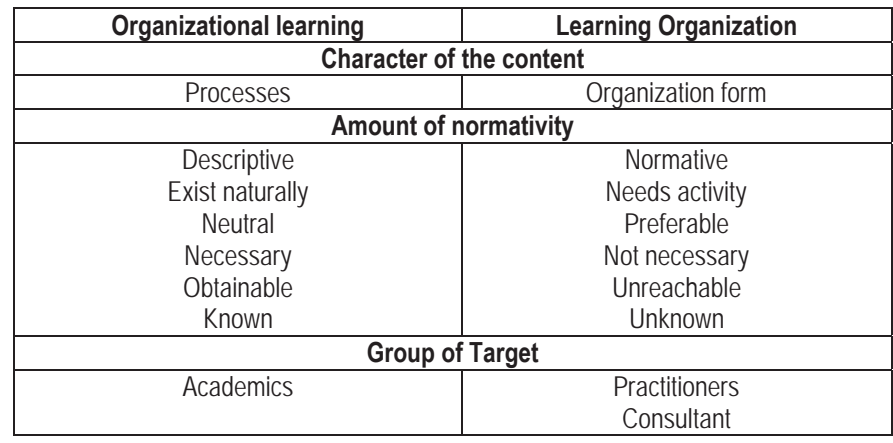

Source: Bordum (2001)

Based on the observation done by Yeo (2003), it was mentioned that organizational learning can encourage sharing and learning processes of information and experience from one person to many others through an open and simple process. The contents used as learning materials are in accordance with the needs of the organization. After this process runs as it should and continually, it will create a learning organization. Thus the authors analyze that organizational learning is a learning process conducted by the organization, and when the process has run well, it will form a learning organization.

According to the studies conducted by Wu (2014) and Rehman, et al. (2015), there are two dimensions of organizational learning, namely management commitment and continuous learning. In this regard, the role of the management is significant to attempt individuals in the organization willing to take a part in the learning process, additionally it is important for the management to increase the willingness of individuals within the organization to 
participate in the learning activities. Wu (2014) stated that there are four activities that can be done to develop learning activities in an organization: management commitment, system view, openness and experimentation, and knowledge sharing and integration.

\section{Organizational Performance}

SOEs governance performance is set out in the Ministerial Decree No. KEP-100/MBU/2002 on Health Evaluation of State-Owned Enterprises. It is stated that the organizational performance of SOEs is rated based upon three main factors, the field of financial performance with a weighting of $70 \%$, the operational field with a weighting of $15 \%$, and administrative field with a weighting of $15 \%$. In this case, the assessment of organizational performance in the stateowned enterprises is not only measured in terms of the financial achievement, but it is also measured from the other fields such as operations and administration. Ratings of the SOEs are set each year in the annual report approval by the General Meeting of Shareholders or SOE Minister for Public Enterprises. In this assessment, the implementation of knowledge management is particularly not as an indicator of the SOEs performances, but the availability of knowledge in the environment of SOEs is an assessment criterion in the administrative field.

Santos (2012) explained that organizational performance is a part of the strategical management field that has been managed in such a way through criteria and indicators in line with the objectives of the organization. In this case, Santos (2012) explained that at least the organizational performance can be analyzed from the perspective of financial and non-financial. From a financial standpoint, the performance of the organization is aimed to provide information related to the achievement of income, financial growth, product value and market value, additionally the value of financial performance is also created as a responsibility toward the investors who have invested their capital in an organization.

Santos (2012) explained that there are seven indicators to measure organizational performance, namely: (1) profitability; (2) growth; (3) market value; (4) customer satisfaction; (5) employee satisfaction; (6) environmental performance; (7) social performance. Rehman, et al (2015) mentioned that the dimensions of the overall organizational performance is measured by four criteria, namely: (1) operational excellence, (2) customer intimacy, (3) product leadership, and (4) financial achievement.

\section{Method of Research}

The approach used in this study is causality. This study is aimed at answering three hypotheses which have been collated by the previous authors. The hypotheses are as follows:

$\mathrm{H}_{1}$. The implementations of knowledge management influence the performances in six SOE headquarters

$\mathrm{H}_{2}$. The implementations of knowledge management influence the organizational learning in six SOE headquarters

$\mathrm{H}_{3}$. The processes of organizational learning affect the performances of six SOEs headquarters

In this research, the writers will use quantitative and qualitative data. The qualitative data was obtained by the author through unstructured interviews with the heads of human resources unit in each office of the objects of study. The qualitative data is widely used by the authors to equip and sharpen the research background. In addition to qualitative data, the authors also use quantitative data to get a complete picture related to the implementation of knowledge management, organizational learning, and organizational performance. The quantitative data is processed and used to answer three research hypotheses.

This study was conducted in a population of human resource units in six SOEs headquarters in Indonesia. The total population of this study is 247 . The researchers compiled a questionnaire to be answered by the respondents. A total of 27 questions was presented using a Likert scale from 1 (strongly disagree) to a value of 7 (strongly agree). To perform the analysis of quantitative data, Structural Equation Model of data processing technique is done in this study. Schumacker (2004) explained that

'structural equation modeling uses various types of models to depict relationships among observed variables, with the same basic goal of providing a quantitative test of a theoretical'

One of the benefits of using SEM analysis technique is its ablility to test the validity of a theory or model that has been made in research on a population. Structural equation model or SEM has several other names, such as covariance structure analysis, latent variables analysis, confirmatory factor analysis, and analysis of linear structural relations. SEM is a second generation multivariate analysis technique that combines factor analysis and path analysis. In the modeling analysis of SEM, it is possible to do three kinds of activities simultaneously, namely checking the validity and reliability of 
the instrument or commonly known as Confirmatory Factor Analysis (CFA), testing the model of relationship among variables, and obtaining a suitable model for prediction. In this case, the researchers will test the questionnaire using confirmatory factor analysis through the stages of reliability and validity test of the instrument, from the analysis, the model that qualifies for the 8 criteria of goodness of fit is considered as the fit model, which means that the indicators used can measure the variables. SEM testing measurements to be taken in this study are: (1) confirmatory factor analysis; (2) goodness of fit assumption test; and (3) hypothesis test calculation

\section{The Result of the Study and Discussion}

Based on the results of questionnaires, the authors have successfully collected 193 data from the respondents. After conducting a further analysis on the overall data collected, the authors put aside 4 biased, incomplete and outlier data, so that the data analyzed further were from 189 respondents. The data were processed as follows: (1) Evaluating the measurement model by testing the validity and reliability of first-order construct; (2) Assessing the overall fit of the model through goodness of fit criteria, and (3) Analyzing the observed variables to answer the hypotheses through regression model testing in the SEM method. The overall analysis was done with the help of AMOS software version 22.

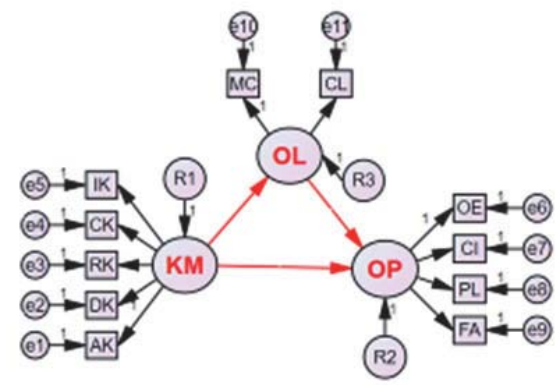

Figure 5. Research Model Retrieved from AMOS 22

\subsection{CFA Evaluation}

In SEM analysis, CFA is conducted to test the validity and reliability of the latent constructs. In this study, the latent constructs consist of: knowledge management, organizational learning, and organizational performance. CFA first-order was done with the analysis results as follows:

Table 2. The Value of Normality Assessment

\begin{tabular}{|c|cccccc|}
\hline Variable & min & Max & skew & c.r. & kurtosis & c.r. \\
\hline CL & 1.000 & 5.588 & -.246 & -1.380 & .084 & .235 \\
MC & 1.000 & 5.556 & -.095 & -.531 & -.206 & -.578 \\
FA & 1.000 & 5.539 & -.114 & -.638 & -.154 & -.433 \\
PL & 1.000 & 5.679 & -.143 & -.802 & -.146 & -.409 \\
Cl & 1.000 & 5.209 & -.145 & -.815 & -.185 & -.518 \\
OE & 1.000 & 5.679 & -.098 & -.550 & -.144 & -.405 \\
IK & 1.000 & 5.579 & -.091 & -.511 & -.299 & -.838 \\
CK & 1.000 & 5.207 & -.192 & -1.077 & -.054 & -.153 \\
RK & 1.000 & 5.465 & -.131 & -.735 & -.148 & -.415 \\
DK & 1.000 & 5.439 & -.159 & -.890 & -.099 & -.279 \\
AK & 1.000 & 5.398 & -.144 & -.809 & -.096 & -.271 \\
Multivariate & & & & & 31.055 & 12.623 \\
\hline
\end{tabular}

Based on the values in Table 2, it is known that all items have the cr value of $\leq 2.58$, therefore all items are declared valid. This means all items or constructs prepared by the authors are considered to be able to reflect their latent variables. Schumacker (2004) stated that if the value of the loading factor on the measurement of the CFA was> 0.6, 
meaning the indicator can be accepted and a further analysis can be carried out. In this study, the overall value of the loading factor reached more than 0.6 so that the entire item and variable forming dimensions are accepted and a further analysis can be done.

Table 3. The Value of Loading Factor of Knowlegde Management Variable

\begin{tabular}{|cccc|c|}
\hline \multicolumn{3}{|c|}{ Variable Explanation } & Loading Factor & Value \\
\hline KM1 & $<---$ & Iden & 0.79 & Valid \\
\hline KM2 & $<---$ & Iden & 0.834 & Valid \\
\hline KM3 & $<---$ & Iden & 0.753 & Valid \\
\hline KM4 & $<---$ & Creat & 0.772 & Valid \\
\hline KM5 & $<---$ & Creat & 0.649 & Valid \\
\hline KM6 & $<---$ & Repr & 0.831 & Valid \\
\hline KM7 & $<---$ & Repr & 0.692 & Valid \\
\hline KM8 & $<---$ & Repr & 0.766 & Valid \\
\hline KM9 & $<---$ & Repr & 0.784 & Valid \\
\hline KM10 & $<---$ & Dist & 0.626 & Valid \\
\hline KM12 & $<---$ & Dist & 0.616 & Valid \\
\hline KM11 & $<---$ & Adop & 0.771 & Valid \\
\hline KM13 & $<---$ & Adop & 0.817 & Valid \\
\hline
\end{tabular}

Based on the results of the calculations the authors can describe that all of the items (13 items) are proven to be able to encourage knowledge management activities. The item with the highest value is number 2 which is 'knowledge orientation', while the item with the lowest score is item number 2, namely 'attention to customers'. The values indicate that the activity of knowledge management is influenced more by the orientation of the knowledge belongs to the employees in a company, meanwhile the item of 'attention to customers' still needs to be paid attention at, considering its value is still quite valid.

Table 3. The Value of Loading Factor of Organizational Learning Variable

\begin{tabular}{|c|c|c|c|c|}
\hline \multicolumn{3}{|c|}{ Variable Explanation } & Loading Factor & Value \\
\hline OL14 & $<--$ & Mana & 0.77 & Valid \\
\hline OL15 & $<--$ & Mana & 0.7 & Valid \\
\hline OL16 & $<--$ & Mana & 0.74 & Valid \\
\hline OL17 & $<--$ & Cont & 0.79 & Valid \\
\hline OL18 & <-- & Cont & 0.66 & Valid \\
\hline
\end{tabular}

Based on the results of the calculations, the authors can describe that all of the items ( 5 items) are proven to be able to encourage knowledge management activities. The item with the highest value is item number 17 which is 'learning facilities', whereas the item with the lowest score is item number 18 which is 'motivating unit'. These values indicate that the activity of organizational learning is influenced more by the learning facilities provided by companies to the employees, whereas the activities to motivate employees still needs to be paid attention at as it is declared valid.

Table 4. The Value of Loading Factor of Organizational Learning Variable

\begin{tabular}{|cccc|c|}
\hline \multicolumn{2}{|c|}{ Variabel } & Explanation & Loading Factor & Value \\
\hline OP19 & $<---$ & Oper & 0.814 & Valid \\
\hline OP20 & $<---$ & Oper & 0.877 & Valid \\
\hline OP21 & $<---$ & Oper & 0.91 & Valid \\
\hline OP22 & $<---$ & Cust & 0.87 & Valid \\
\hline OP23 & $<---$ & Cust & 0.888 & Valid \\
\hline OP24 & $<---$ & Prod & 0.912 & Valid \\
\hline OP25 & $<---$ & Prod & 0.782 & Valid \\
\hline OP26 & $<---$ & Fina & 0.915 & Valid \\
\hline OP27 & $<---$ & Fina & 0.903 & Valid \\
\hline
\end{tabular}

Based on the results of the calculations above the authors can describe that all items ( 9 items) have been shown to be able to encourage the activity of organizational performance. The item with the highest value is item number 24 of 'product quality', while the item that has the lowest score is item number 25 , namely 'product function improvement'. 
These values indicate that the level of performance of an organization is influenced more by the quality of the products produced by the company, while the product function improvement still needs to be considered as it is in valid category.

To determine the reliability of a model in SEM, it requires the calculation of Average Variance Extracted (AVE) and the Composite Reliability (CR) for each construct using the formula in the overall value of loading factor. Based on the calculation analysis of the authors, an AVE score of 2.88 and CR value of 3.88 are attained. Therefore, it can be seen that the values of AVE and CR in the research model have already fullfilled the recommended requirements of ST> 0.5 and $\mathrm{CR}>0.7$.

\subsection{Goodness of Fit Test}

A test on the value of goodness of fit is one of the requirements in processing data using SEM technique. This test is intended to identify whether the research model that has been made is the right one to be used in certain objects of study. In processing data using SEM, there are 25 sizes of fit model produced in the criteria of Goodness of Fit, but not all sizes of the fit should be outlined. In this study, the authors will present 10 goodness of fit criteria according to which had been recommended by Schumacker (2004).

Table 5. The Value of Goodness of Fit

\begin{tabular}{|c|c|c|c|c|}
\hline No & Goodness of Fit & $\begin{array}{c}\text { Criteria } \\
\text { Latan (49:2013) }\end{array}$ & Research Result & Explanation \\
\hline 1 & CMIN/DF & $\leq 2$ & 1,377 & Accepted \\
\hline 2 & RMSEA & $\leq 0,06$ & 0,045 & Accepted \\
\hline 3 & CFI & $>0,95$ & 0,992 & Accepted \\
\hline 4 & IFI & $>0,95$ & 0,992 & Accepted \\
\hline 5 & TLI & $>0,95$ & 0,987 & Accepted \\
\hline 6 & PNFI & $>0,6$ & 0,566 & Rejected \\
\hline 7 & PCFI & $>0,6$ & 0,577 & Rejected \\
\hline 8 & AIC & default model < saturated & $112<132$ & Accepted \\
\hline 9 & BCC & default model < saturated & $116<141$ & Accepted \\
\hline 10 & ECVI & default model < saturated & $0,596<702$ & Accepted \\
\hline
\end{tabular}

The data in Table 5 above has represented each of the main criteria (CMIN, RMSEA), baseline fit (CFI, IFI, NFI, RFI, TLI), parsimony fit (PNFI, PCFI), and information theory (AIC, BIC, CAIC , BCC, ECVI, MECVI). Based on these data, we can know that the parsimony fit criterion states 'rejected'. In this case, it is because the composition of the research model is not used for comparisons with other models. Nevertheless, the overall Goodness of Fit can be accepted because the main criterion and other criteria state 'acceptable', the model is declared fit to do other data processings. The meaning of the value of goodness of fit shows that a research model is considered good because it is based a strong theory and deserves to be further processed. In this case, the model which has been prepared by the authors can be used to measure or determine the effect of knowledge management activities through a mediator variable of organizational learning on the object of research

\subsection{Answering the hyphotheses}

Based on the estimated value which has been done by the authors, it can be seen that the two variables: knowledge management and organizational learning positively affect organizational performance, it is evidenced by a significant $P$ value at 0.001 and C.R value $>1.96$

Table 6. The Value of Model Signification

\begin{tabular}{|l|ccccc|}
\hline \multicolumn{1}{|c|}{ Variable } & Estimate & S.E. & C.R. & P & Label \\
\hline KM & .585 & .090 & 6.536 & ${ }^{* * *}$ & par_21 \\
OL & .193 & .056 & 3.422 & ${ }^{* \star *}$ & par_23 \\
\hline
\end{tabular}

Thus, the research hypotheses can be answered as follows: 
- $\mathrm{H}_{0}$ is rejected, $\mathrm{H}_{1}$ is accepted, and thus there is a significant influence of knowledge management variable to the variable of organizational performance.

- $\quad \mathrm{H}_{0}$ is rejected, $\mathrm{H}_{1}$ is accepted, and thus there is significant influence of knowledge management variable to variable organizational learning.

- $\mathrm{H}_{0}$ is rejected, $\mathrm{H}_{1}$ is accepted, and thus there is significant influence of organizational learning variable to variable organizational performance.

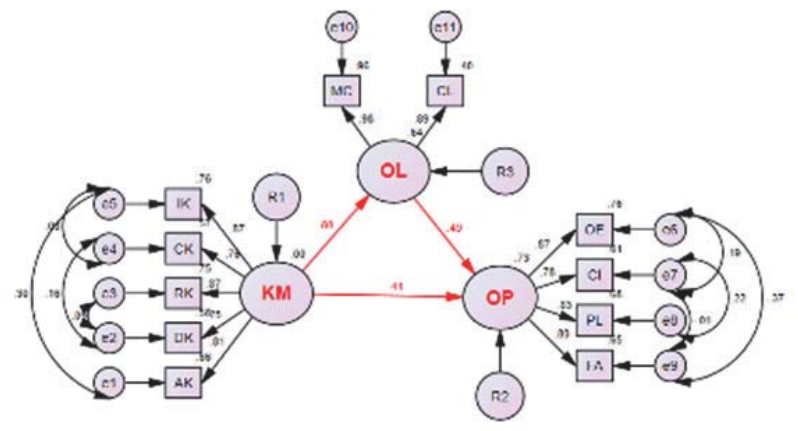

Figure 5. The Value of Standarized Estimates

The variable coefficient value of knowledge management toward organizational learning is 0.8 , it shows that the influence of the implementation of knowledge management affects $80 \%$ toward the activity of organizational learning. The coefficient value of knowledge management toward organizational learning is 0.412 which indicates that the effect of knowledge management implementation on organizational performance is $41 \%$. Furthermore, the coefficient value of organizational learning on organizational performance is 0.486 which indicates that the effect of the implementation of organizational learning toward organizational learning is $48.60 \%$.

\section{Conclusion}

Based on the results of this study, it can be concluded as follows: (1) The implementation of knowledge management is proven to have a significant influence on organizational performance. In this case, the value of the effect is $41 \%$. (2) The implementation of knowledge management is proven to have a significant influence on organizational learning. In this case the value of the effect is $80 \%$. (3) Organizational learning is proven to have a significantly affect on organizational performance. In this case, the value of the effect is $49 \%$.

\section{References}

Andone, I. I. (2009). Measuring the performance of corporate knowledge management systems. Journal of Informatica Economic. 13 , $24-31$.

Andreeva, T., \& Kianto, A. (2012). Does knowledge management really matter? Linking knowledge management practices, competitiveness and economic performance. Journal of Knowledge Management. 16, $617-636$.

Bagorogoza, J. K., Waal A. D., Henrik, H.J V., \& Walle V. (2013). A critical assessment of the high performance framework in the ugandan finance sector. Botswana Journal of Business. 6, $1-16$.

Bordum, A. (2010). The strategic balance in a change management perspective. Journal of Society and Business Review. 5, $245-258$.

Carton, R. B., \& Hofer, C. W. (2006). Measuring Organizational Performance (Metrics for Entrepreneurship and Strategic Management Research. Massachusetts, USA: Edward Elgar Publishing Limited.

Chien, S. Y., \& Tsai, C. H. (2012). Dynamic capability, knowledge, learning, and firm performance. Journal of Organizational Change Management. 25, $434-444$.

Darroch, J. (2005). Knowledge management, innovation, and firm performance. Journal of Knowlede Management. 9, 101 - 115.

Fajriah, L. R., (2015), Ekonomi lesu, Rini minta BUMN geber kinerja ekbis, sektor riil. [Sluggish economy, Rini asked state-owned companies to push the work performance of business sector, real sector]. [Online] Available: http://ekbis.sindonews.com/read/1032668/34/ekonomi-lesu-rini-minta-bumn-geber-kinerja-1439455146 (January 9, 2016)

Figurska, I., \& Sokot, A. (2016). The process of knowledge acquisition with the use of various teaching methods and its effect on the creativity of employees of the creative sector. Journal of Social Science. 7. 143-152. 
Gavrea, C., llies, L., \& Stegerean, R. 2011. Determinants of organizational performance : the case of romania. Journal of Management \& Marketing. 6, $285-300$.

Hsu, I. C., \& Sabherwal. (2011). From intellectual capital to firm performance: the mediating role of knowledge management capabilities. Journal of Transaction on Engineering Management. 58, 626 - 642.

Kementerian Pendayagunaan Aparatur Negara dan Reformasi Birokrasi. (2011). Pedoman pelaksanaan program manajemen pengetahuan [The ministry of state aparatus empowerment and beaurocracy reforms (2011). The implementation guideline concerning knowledge management program]. Indonesia: Published Internally by The Government of The Republic of Indonesia.

Mills, A. M., \& Smith, T. S. (2011). Knowlegde management and organizational performance: a decomposed view. Journal of Knowledge Management. 15, $156-171$.

Moeljono, D. (2004). Reinvensi BUMN : Empat strategi membangun BUMN kelas dunia [The Re-invention of state-owned companies: Four strategies to develop world class state-owned companies]. Jakarta: PT Elex Media Komputindo.

Molina, C., \& Callahan J. L. (2009). Fostering organizational performance. Journal of European Industrial Training. 33, 388 - 400.

Quintane, E. R., Casselman, M. B., Reiche, S., \& Nylund, P. A. (2011). Innovation as a knowledge based outcome. Journal of Knowledge Management. 15, $928-947$.

Rasula, J., Vuksic, V. B., \& Stemberger, M. I. (2012). The impact of knowledge management on organizational performance. Journal of Economic and Business Review. 14, $147-168$.

Rehman, W. U., Asghar, N., \& Ahmad, K. (2015). Impact of knowledge management practices on firms performance : a mediating role of business process capability and organizational learning. Pakistan Economic and Social Review. 53, $47-80$

Salwa, M., \& Susanty, A. I. (2016). Measuring employee readiness for knowledge management in PT. Mineral Indonesia. Journal of Social Science and Humanities. 24 (S). $27-34$.

Santos, J. B., \& Brito, L. A. L. (2012). Toward a subjective measurement model for firm performance. Brazilian Administration Review. 9 , $95-117$.

Schumacker, R. E., \& Lomax, R. G. (2004). A beginner's guide to structural equation modeling: second edition. Lawrence Erlbaurn Associates. (pp. 196 - 208). New Jersey: Inc Publisher.

Seidman, D. (2014). From the knowledge economy to the human economy. Harvard Business Review: Article of Economy.

Spreitzer, G., \& Porath, C. (2012). Creating sustainable performance. Harvard Business Review. Article of Assessing Performance.

Undang-Undang Republik Indoneisa. (2013). Badan usaha milik negara. Undang-Undang Republik Indonesia Nomor 19 Tahun 2003 [The law of the republic of Indonesia (2013). State-owned companies. The law of the republic of Indonesia No.19 in 2003]. Indonesia: Published by the President of the Republic of Indonesia.

Wu, I. L., \& Chen, J. L. (2014). Knowledge management driven firm performance: the roles of business process capabilities and organizational learning. Journal of Knowledge Management. 18, 1141 - 1164.

Yeo, R. (2003). Linking organizational learning to organizational performance and success: singapore case studies. Journal of Leadership and Organization Development. 24, $70-83$. 
ISSN 2039-2117 (online)

ISSN 2039-9340 (print)
Mediterranean Journal of Social Sciences MCSER Publishing, Rome-Italy
Vol 8 No 3

May 2017 